\title{
Studies on the Molecular Variability of Sterility Mosaic Disease of Pigeonpea in Tamil Nadu State, India
}

\author{
S. Baskar ${ }^{1 *}$, T. K. S. Latha ${ }^{1}$, G. Karthikeyan ${ }^{1}$, M. Sudha ${ }^{2}$, and Basavaprabhu L. Patil ${ }^{3}$ \\ ${ }^{1}$ Department of Plant Pathology, ${ }^{2}$ Department of Plant Biotechnology, Tamil Nadu \\ Agricultural University, Coimbatore-03, India \\ ${ }^{3}$ ICAR-Indian Institute of Horticulture Research, Bengaluru- 560089, India \\ *Corresponding author
}

\begin{tabular}{|c|c|}
\hline & B \\
\hline & \multirow{3}{*}{$\begin{array}{l}\text { Sterility mosaic disease (SMD) is one of the major biotic problems for pigeonpea } \\
\text { production in the Indian subcontinent. A systematic survey and comprehensive } \\
\text { study was carried out to determine the incidence of Pigeonpea sterility mosaic } \\
\text { virus (PPSMV) and molecular variability among disease causing agents in Tamil } \\
\text { Nadu state of southern India during the } 2019 \text { Kharifseason. The results indicate } \\
\text { there was a variation in SMD incidence among the districts. In Tamil Nadu SMD } \\
\text { incidence was observed ranging from } 3.6 \% \text { to } 21.3 \% \text {. In this study we analysed } \\
\text { the SMD infected samples from } 12 \text { locations of major pigeonpea growing regions } \\
\text { of Tamil Nadu state. All isolates contain both PPSMV-1 and PPSMV-2 as mixed } \\
\text { infection none of the sample was positive for PPSMV-I or PPSMV- } 2 \text { alone. } \\
\text { Overall our study provides evidence for variability and increase in disease } \\
\text { incidence. }\end{array}$} \\
\hline & \\
\hline & \\
\hline
\end{tabular}

\section{Introduction}

Pigeonpea (Cajanus cajan, L.) is a major pulse crop grown in over 5 million ha with an annual production of more than 3 million tonnes. Nearly $90 \%$ of its cultivation takes place in India and Nepal, followed by Africa (6\%), the Caribbean (2\%) and other Southeast Asian countries. Pigeonpea sterility mosaic virus (PPSMV), a species of the genus Emaravirus, is the causal agent of sterility mosaic disease (SMD) of pigeonpea [Cajanus cajan (L.) Millsp], and transmitted by mites
(Aceria cajani) (Mitra et al., 1931; Elbeaino et al., 2014; Jones et al., 2004; Kumar et al.2000). SMD is characterized by stunted and bushy plants, leaves of reduced size with chlorotic rings or mosaic symptoms, and partial or complete cessation of flower production (i.e. sterility). SMD has variable symptomatology, within which three major syndromes are recognized severe mosaic and sterility (partial or complete cessation of flower production), mild mosaic with partial sterility and chlorotic ring spots with no apparent sterility. Infected perennial and 
volunteer plants serve as a source for both the virus and its vector mites which play an important role in the disease cycle (Kulkarniet al.2002).

Two emaravirus species, Pigeonpea sterility mosaic emaravirus 1 (PPSMV-1) and Pigeonpea sterility mosaic emaravirus 2 (PPSMV-2) are associated with sterility mosaic disease (SMD) of pigeonpea contains negative-sense dsRNA genomes. PPSMV-1 and PPSMV-2were reported to contain six genomic RNA segments. The largest segment, RNA-1 is 7022 nt in length codes for RNAdependent RNA polymerase RNA-2, witha sequence length of $2223 \mathrm{nt}$, codes for glycoproteins RNA-3, with a sequence length of $1442 \mathrm{nt}$, codes for nucleocapsid protein RNA-4, with a sequence length of $1563 \mathrm{nt}$, codes for movement protein and RNA-5, with a sequence length of $1689 \mathrm{nt}$, codes for $\mathrm{p} 5$ and sequence length of $1094 \mathrm{nt}$, codes for p6 these protein has unknown function (Elbeaino et al., 2013,2014,2015). The first four RNA segments of PPSMV-2 share higher sequence similarity with Fig mosaic virus(FMV) than withPPSMV-1 (Patil et al., 2015).

To develop any virus management strategies, it is important to understand the population structure of the viruses, for which sequence variability study is essential. In this study, we investigated the current variability of PPSMV isolates present in Tamil Nadu state, India. We analyzed RNA-4 of PPSMV in SMD infected leaves collected form 12 locations of Tamil Nadu state.

\section{Materials and Methods}

\section{Selection of locations}

For data collection, the details on major pigeonpea growing locations in Tamil Nadu was obtained from different Agricultural Research Stations, Krishi Vignan Kendra and
State Agricultural Universities across Tamil Nadu and surveyed for SMD incidence.

\section{Survey and disease incidence}

Major Pigeonpea growing districts of the Tamil Nadu state were surveyed for the occurrence of SMD during Kharif2019 the Pigeonpea crop was in the middle of the maturity and flowering stage (30-45 Days After Sowing- DAS). Infected leaf samples were showing characteristic symptoms like severe mosaic, ring spot, reduction in leaf size and stunted growth.

The locations are field of TNAU, Devarayapuram and Thondamuthur villages of Coimbatore district. Elur, Perumpallipatti and Kandipalayam villages of Namakkal district Attaiyampatti, Papparapatti and Minnakal villages of Salem district Arachi and Keelakkunuppatti villages of Trichy district. It was represented in Table 1. All these leaf samples were immediately brought to TNAU Coimbatore and snap frozen in liquid nitrogen and stored in a $-80^{\circ} \mathrm{C}$ freezer for further use. The disease incidence of every field was calculated by counting the number of infected plants from 500 randomly selected plants and per cent SMD incidence was calculated by using the formula

$\%$ SMD incidence $=\underline{\text { Number of infected plants }} \times 100$.

\section{Inoculum maintenance by the leaf-stapling technique}

Aceria cajani mites were observed under Stereo zoom binocular microscope to confirm each infected leaf has sufficient mite population to transmit the virus particles. Then the mites were inoculated into the susceptible variety ICP8863 at two leaf stage through leaf-stapling technique. The pots were covered by insect proof cage. Symptom 
development was observed in 10 to 15 days. It was represented in Fig. 2.

\section{Total RNA extraction and reverse transcription-polymerase chain reaction (RT-PCR)}

\section{Leaf sample and total RNA extraction}

Pigeonpea leaves exhibiting typical SMD symptoms were collected from 12 locations in Tamil Nadu state. $100 \mathrm{mg}$ leaf tissue of symptomatic and healthy pigeonpea was used for RNA extraction, by grinding in liquid nitrogen to a fine powder. Total RNA was extracted from leaf powder using Trizol method. The RNA purity and quality were assessed using a spectrophotometer (NanoDrop 8000, Thermo-Fisher Scientific) and stored at $-20{ }^{\circ} \mathrm{C}$.

\section{Reverse transcription- polymerase chain reaction (RT- PCR)}

RT-PCR was performed as per the protocol suggested by Elbeaino et al., (2015). The total RNA was reverse transcribed using a cDNA synthesis kit (Verso cDNA Synthesis kit, thermos Fisher Scientific India) with RT Random primers and other components following the manufacturer's instruction. PCR was performed using Eppendorf - Master Cycler nexus gradient S (Eppendorf, A G, Hamburg, Germany) in a $20 \mu 1$ reaction mixture containing $10 \mu \mathrm{l}$ of Hot Start Green Master Mix (2X), 1.0 $\mu$ l of each forward and reverse primer of RNA-4, $2.0 \mu 1$ of cDNA and rest of the PCR water.

The PCR mixture tube was incubated by one cycle of denaturation at $94{ }^{\circ} \mathrm{C}$ for $4 \mathrm{~min}$, followed by 35 cycles at $92{ }^{\circ} \mathrm{C}$ for 30 seconds, $45-65{ }^{\circ} \mathrm{C}$ for 30 seconds and $72{ }^{\circ} \mathrm{C}$ for 30 seconds. The final extension was at 72 ${ }^{\circ} \mathrm{C}$ for $7 \mathrm{~min}$. The amplification products were resolved in a $1 \%$ TBE agarose gel, visualized and documented by a Gel-doc system.
Specific primers used for RNA-4 amplification was represented in Table $1.1 \mathrm{~kb}$ DNA ladder was used as a marker. The PCR amplified fragments of the isolates yielded band of around 400bp.

\section{Results and Discussion}

\section{Prevalence of SMD in Pigeonpea in Tamilnadu}

Data on the survey conducted for the occurrence of pigeonpea sterility mosaic disease (SMD) during Kharif 2019 in major pigeonpea growing regions of Tamil Nadu state was summarized in Table 2 and represented in Fig. 1. In the surveyed areas, farmers were cultivating pigeonpea crop under rainfed conditions as sole and intercropped with other pulses and cereals.

In Tamil Nadu, the Pigeonpea was cultivated both as sole crop and inter-cropped with groundnut, pearl millet, sorghum, field bean, horse gram, and finger millet. SMD incidence was observed with varying range from $3.6 \%$ to $21.3 \%$. Among the four districts and 12 locations surveyed for SMD prevalence, the least disease incidence (3.6\%) was observed in Perumpallipatti village Namakkal district, whereas, Trichy, Salem and Coimbatore districts recorded with disease incidences of 4.4, 6.2 and $7.3 \%$ respectively. The highest SMD incidence was recorded in Thondamuthur village Coimbatore district $(21.3 \%)$. However, in previous studies, the highest incidence $(37.50 \%)$ of SMD was observed in the Pudukkottai district (Kannaiyan et al., 1984), a range of 0-100\% incidences across Tamil Nadu (Ramakrishnan and Kandaswamy1972). (8.77\%) of SMD was incidence observed in the Coimbatore district (Sayiprathap et al., 2020).

This drastic reduction in the incidence over the past few years could be due to growing of resistant cultivars and adoption of 
prophylactic measures such as removal of ratoon crop and spraying of insecticides to control the disease/vector in the early stage (Sayiprathap et al., 2020). But this study showed increase in disease incidence compare to previous reports. The reason for disease increase was may be molecular variability of the two strains.

Table.1 Specific primers of RNA-4 used for variability analysis

\begin{tabular}{|c|c|l|c|}
\hline S. No & CODE & \multicolumn{1}{|c|}{ PRIMER } & AMPLICON SIZE \\
1. & PPSMV-1 & F- CACCTGCACGTTTTCCTATTTTTN & $400 \mathrm{bp}$ \\
& & R- TTAGGTAGCTTCACCAATTTTTN & \\
\hline 2. & PPSMV-2 & F- CACCATGATGCCTAGCACCTCN & $400 \mathrm{bp}$ \\
\cline { 3 - 3 } & & R- TTACTGACTTCACCTATTAC & \\
\hline
\end{tabular}

Table.2 Survey of PPSMV infected leafs in Coimbatore, Namakkal, Salem and Trichy districts for assessing disease incidence

\begin{tabular}{|c|c|c|c|c|c|c|c|}
\hline S.No & Location & Code & $\begin{array}{l}\text { Latitude/ } \\
\text { Longitude }\end{array}$ & $\begin{array}{c}\text { PPSMV } \\
\text { type }\end{array}$ & $\operatorname{PDI}(\%)$ & Variety & Symptoms \\
\hline \multirow[t]{3}{*}{1.} & $\begin{array}{l}\text { Coimbatore } \\
\text { Field of TNAU }\end{array}$ & $\mathrm{C} 1$ & $\begin{array}{l}11.0123^{\circ} \mathrm{N} / \\
76.9355^{\circ} \mathrm{E}\end{array}$ & $\begin{array}{c}\text { Mixed } \\
\text { infection }\end{array}$ & 13.5 & Co-5, Co-8 & $\begin{array}{l}\text { Severe mosaic, } \\
\text { complete sterility }\end{array}$ \\
\hline & Devarayapuram & $\mathrm{C} 2$ & $\begin{array}{c}10.9946^{\circ} \mathrm{N} / \\
76.8124^{\circ} \mathrm{E}\end{array}$ & $\begin{array}{c}\text { Mixed } \\
\text { infection }\end{array}$ & 7.3 & $\begin{array}{l}\text { Co-1, Co (Rg)- } \\
7\end{array}$ & $\begin{array}{l}\text { Mosaic, partial } \\
\text { sterility }\end{array}$ \\
\hline & Thondamuthur & C3 & $\begin{array}{c}10.9899^{\circ} \mathrm{N} / \\
76.8409^{\circ} \mathrm{E}\end{array}$ & $\begin{array}{c}\text { Mixed } \\
\text { infection }\end{array}$ & 21.3 & $\begin{array}{l}\mathrm{Co}-1, \mathrm{Co}(\mathrm{Rg})- \\
7\end{array}$ & $\begin{array}{l}\text { Severe mosaic, } \\
\text { complete sterility }\end{array}$ \\
\hline \multirow[t]{3}{*}{2.} & $\begin{array}{c}\text { Namakkal } \\
\text { Perumpallipatti }\end{array}$ & N1 & $\begin{array}{l}10.9945^{\circ} \mathrm{N} / \\
76.9248^{\circ} \mathrm{E}\end{array}$ & $\begin{array}{c}\text { Mixed } \\
\text { infection }\end{array}$ & 3.6 & $\begin{array}{l}\text { Co-6, Vamban- } \\
2,\end{array}$ & $\begin{array}{c}\text { Mosaic, partial } \\
\text { sterility }\end{array}$ \\
\hline & Kandipalaiyam & $\mathrm{N} 2$ & $\begin{array}{l}11.2704^{\circ} \mathrm{N} / \\
77.9467^{\circ} \mathrm{E}\end{array}$ & $\begin{array}{c}\text { Mixed } \\
\text { infection }\end{array}$ & 11.5 & $\begin{array}{l}\text { Co-6, LRG-41, } \\
\text { BRG-1,2 }\end{array}$ & $\begin{array}{l}\text { Severe mosaic, } \\
\text { complete sterility }\end{array}$ \\
\hline & Elur & N3 & $\begin{array}{l}11.3506^{\circ} \mathrm{N} / \\
78.1089^{\circ} \mathrm{E}\end{array}$ & $\begin{array}{c}\text { Mixed } \\
\text { infection }\end{array}$ & 12.4 & $\begin{array}{c}\text { Co-6, Vamban- } \\
2,\end{array}$ & $\begin{array}{c}\text { Mosaic, partial } \\
\text { sterility }\end{array}$ \\
\hline \multirow[t]{3}{*}{3.} & $\begin{array}{c}\text { Salem } \\
\text { Attayampatti }\end{array}$ & S1 & $\begin{array}{l}11.5355^{\circ} \mathrm{N} / \\
78.0566^{\circ} \mathrm{E}\end{array}$ & $\begin{array}{c}\text { Mixed } \\
\text { infection }\end{array}$ & 4.4 & $\begin{array}{l}\text { Vamban-2, Co- } \\
6, \text { LGR-41 }\end{array}$ & $\begin{array}{c}\text { Mosaic, partial } \\
\text { sterility }\end{array}$ \\
\hline & Papparapatti & S2 & $\begin{array}{l}11.5246^{\circ} \mathrm{N} / \\
78.0623^{\circ} \mathrm{E}\end{array}$ & $\begin{array}{c}\text { Mixed } \\
\text { infection }\end{array}$ & 8.5 & $\begin{array}{l}\text { Vamban-2, Co- } \\
6, \text { LGR-41 }\end{array}$ & $\begin{array}{l}\text { Severe mosaic, } \\
\text { complete sterility }\end{array}$ \\
\hline & Minnakkal & S3 & $\begin{array}{l}11.5353^{\circ} \mathrm{N} / \\
78.0837^{\circ} \mathrm{E}\end{array}$ & $\begin{array}{c}\text { Mixed } \\
\text { infection }\end{array}$ & 17.8 & $\begin{array}{l}\text { Vamban-2, Co- } \\
6,\end{array}$ & $\begin{array}{l}\text { Severe mosaic, } \\
\text { complete sterility }\end{array}$ \\
\hline \multirow[t]{3}{*}{4.} & $\begin{array}{l}\text { Trichy } \\
\text { Arachi A }\end{array}$ & $\mathrm{T} 1$ & $\begin{array}{l}11.1017^{\circ} \mathrm{N} / \\
78.4787^{\circ} \mathrm{E}\end{array}$ & $\begin{array}{c}\text { Mixed } \\
\text { infection }\end{array}$ & 6.2 & $\begin{array}{l}\text { Vamban-1,2, } \\
\text { Vamban (Rg)- } \\
3, \text { Co-6 }\end{array}$ & $\begin{array}{c}\text { Mosaic, partial } \\
\text { sterility }\end{array}$ \\
\hline & Keelakkunuppatti & $\mathrm{T} 2$ & $\begin{array}{l}11.1243^{\circ} \mathrm{N} / \\
78.6473^{\circ} \mathrm{E}\end{array}$ & $\begin{array}{c}\text { Mixed } \\
\text { infection }\end{array}$ & 13.8 & $\begin{array}{l}\text { Vamban-1,2, } \\
\text { Co-6 }\end{array}$ & $\begin{array}{l}\text { Severe mosaic, } \\
\text { complete sterility }\end{array}$ \\
\hline & Arachi B & $\mathrm{T} 3$ & $\begin{array}{l}11.0896^{\circ} \mathrm{N} / \\
78.4794^{\circ} \mathrm{E}\end{array}$ & $\begin{array}{c}\text { Mixed } \\
\text { infection }\end{array}$ & 15.5 & $\begin{array}{l}\text { Vamban-1,2, } \\
\text { Co-6 }\end{array}$ & $\begin{array}{l}\text { Severe mosaic, } \\
\text { complete sterility }\end{array}$ \\
\hline
\end{tabular}


Fig.1
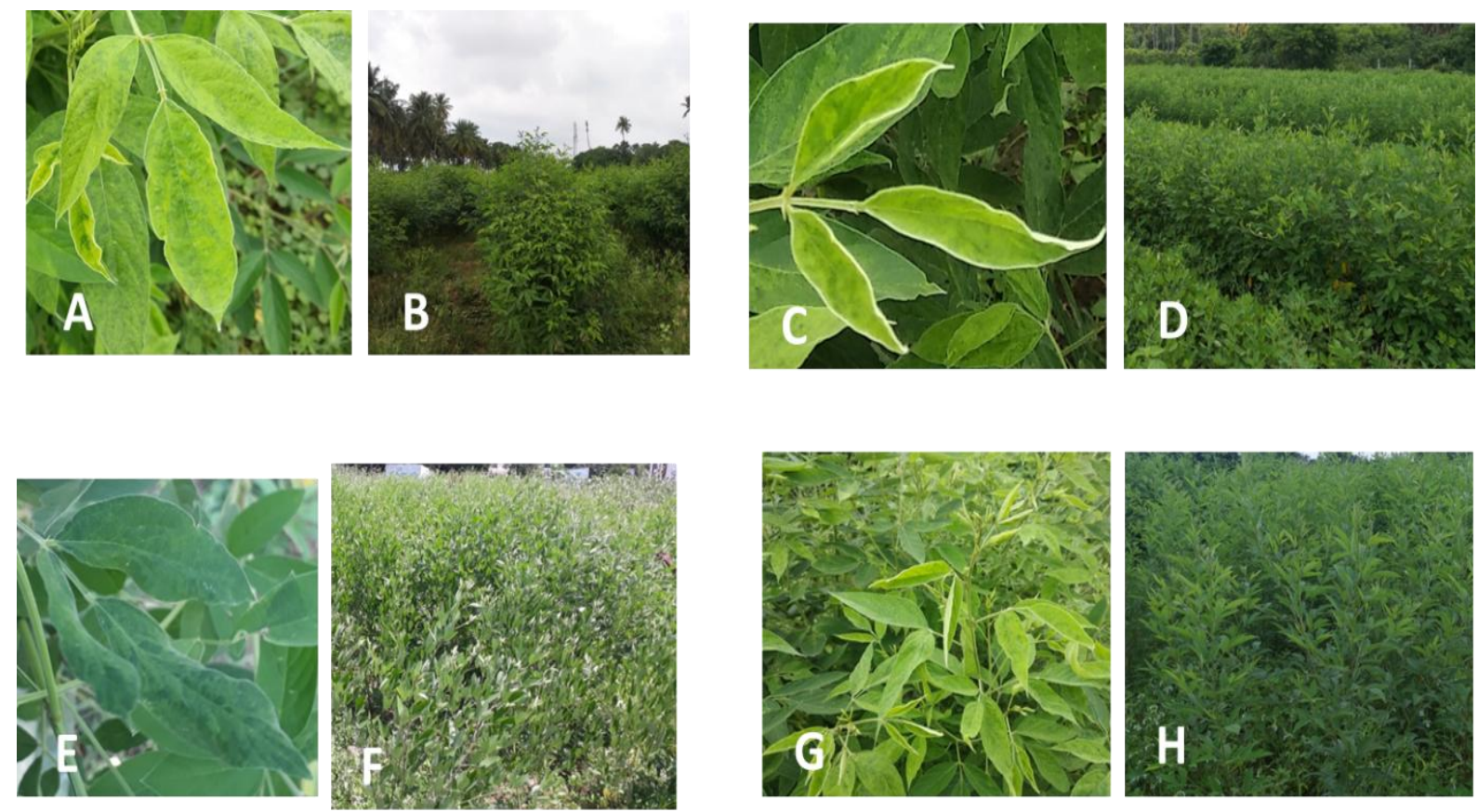

Collection of SMD infected leaf samples A,B - samples collected from Coimbatore, C,D - samples collected from Namakkal, E,F - samples collected from Salem, G,H - samples collected from Trichy

\section{Fig.2}
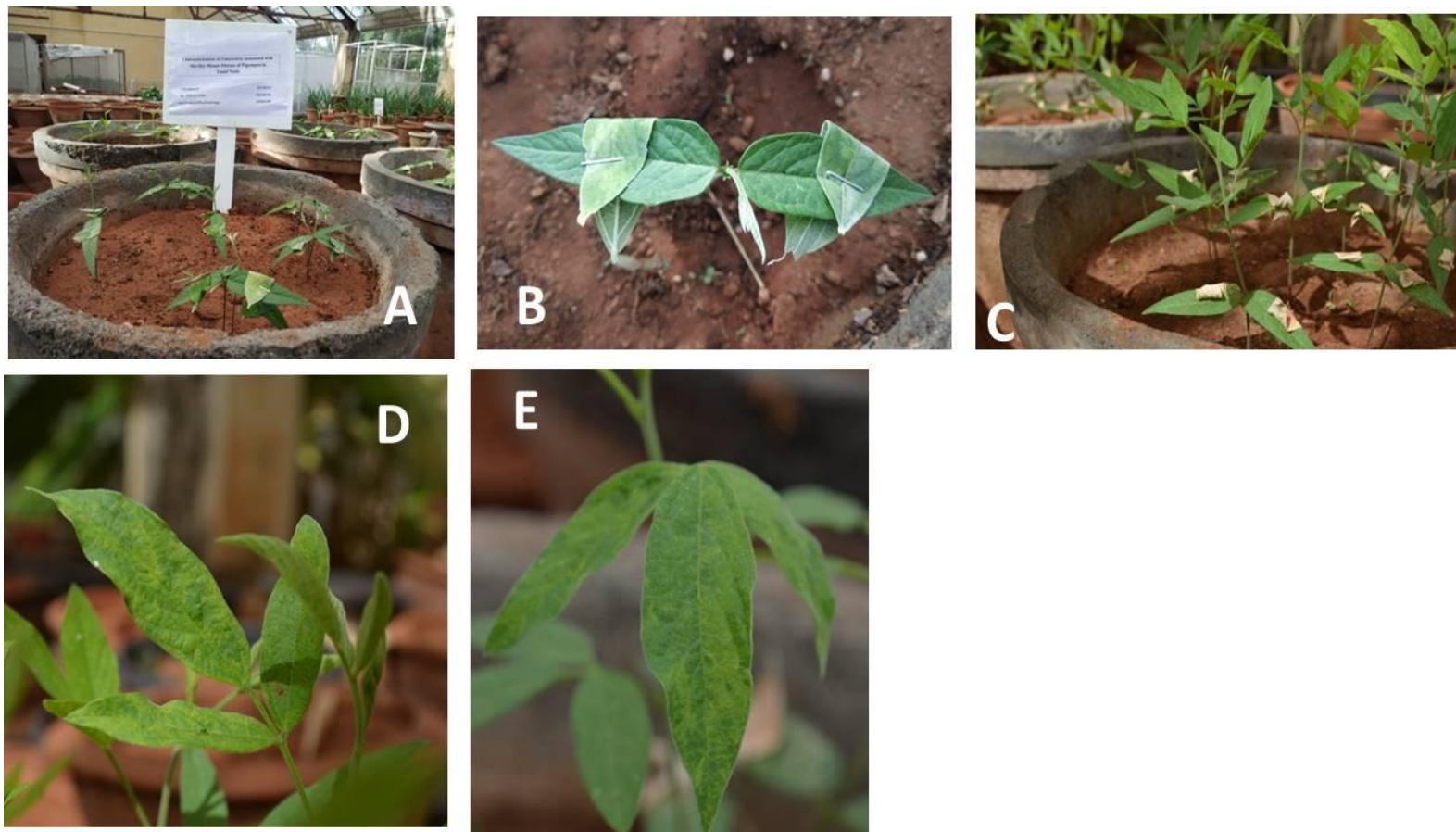

Inoculum maintenance by leaf stapling A - pigeonpea plants with two leaf stage, B - mite inoculation, C -10 days after inoculation, D,E - leaves with mosaic and leaf crinkle 
Fig.3

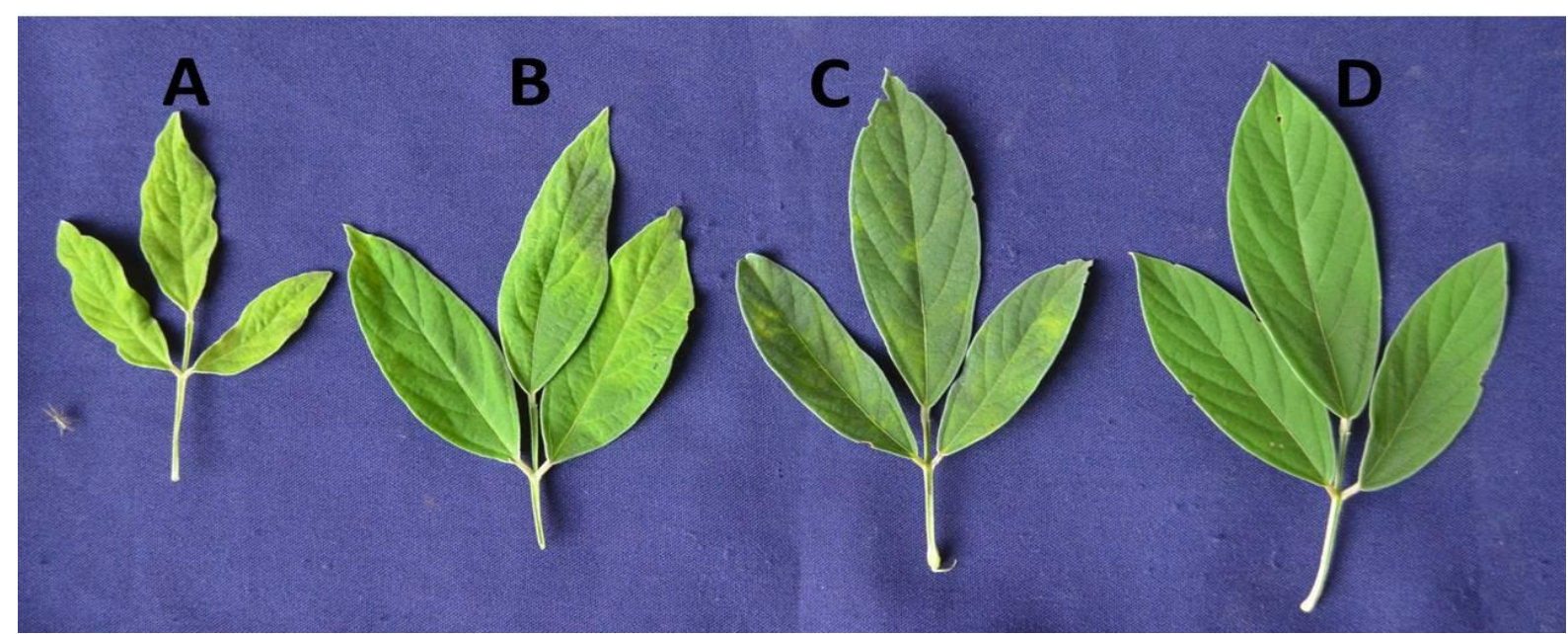

Sterility mosaic virus affected pigeonpea plants exhibiting different kind of SMD symptoms, A - Leaf crinkle with severe mosaic, $\mathbf{B}$ - Mild mosaic, $\mathbf{C}$ - chlorotic ring spots and $\mathbf{D}$ - Healthy leaves

\section{Fig.4}

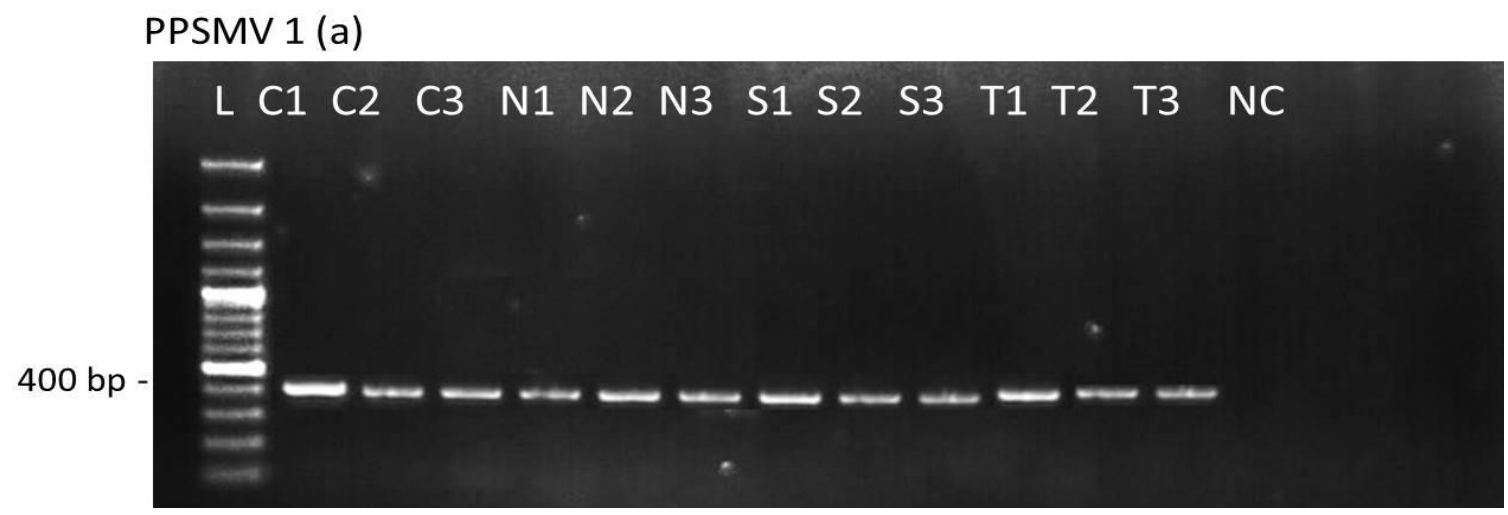

PPSMV 2 (b)

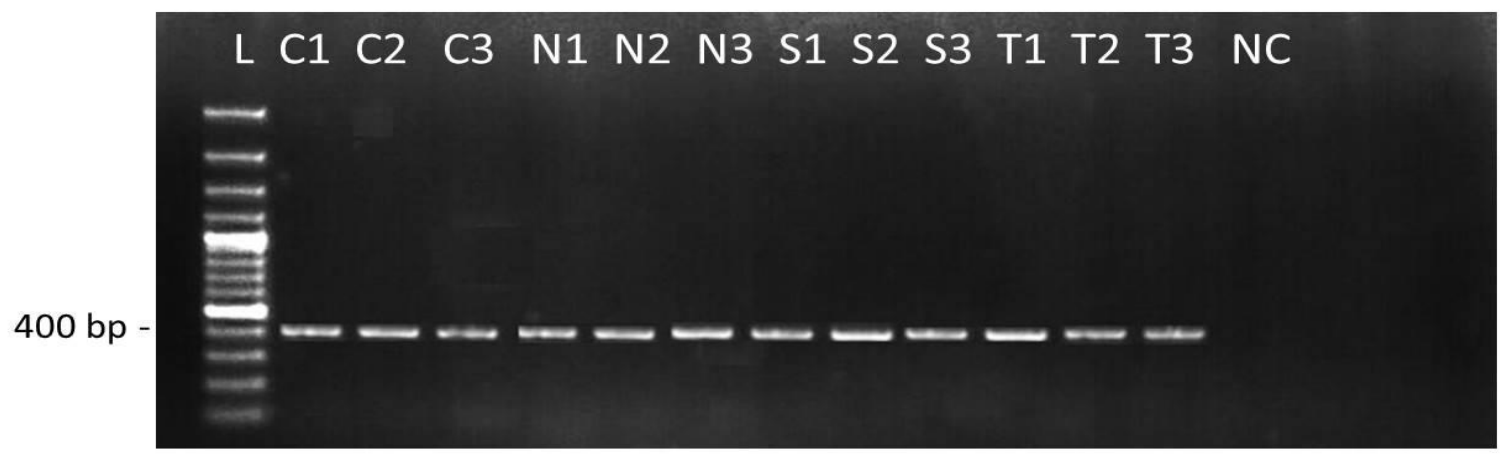

$\mathrm{L}-100 \mathrm{bp}$ lader $\mathrm{NC}$ - negative control

RT-PCR amplification of RNA-4 segment for detection of PPSMV 1(a) and PPSMV 2,(b) in SMD affected pigeonpea samples. Lane L 100 bp DNA ladder; lane C1 - C3 Coimbatore isolates, lane N1 - N3Namakkal isolates, lane S1 - S3 Salem isolates, T1 - T3Trichy isolates, NC - Healthy plant sample as Negative control 
Symptom variability of sterility mosaic disease (SMD) of pigeonpea in field and glass house conditions

SMD infected plants were identified based on symptoms viz., yellow mosaic, chlorotic ring spots on leaves, reduced leaf size, severe stunting, or more vegetative growth. Severity was depending on infection age and variety of the crop. Inoculation of viruliferous mites in 30 to 45 DAS leads to severe mosaic, inoculation after 45 DAS leads to Mild mosaic and inoculation in reproductive stage leads to chlorotic ring spots on leaves. It was represented in Fig. 2 and 3.

\section{RT-PCR for detection of PPSMV-1 and PPSMV-2}

RT-PCR was done for all 12 isolates by using specific primers for RNA-4. All 12 isolates of Tamil Nadu had Both PPSMV-1 and PPSMV-2 as mixed infection. Pati let al., 2015 has reported the presence of PPSMV-2 alone in Coimbatore, but Sayiprathap et al., 2020hasreported both PPSMV-1 and PPSMV-2 present in Coimbatore. It was represented in Fig. 4.

It was proved by our work. Mixed infection in Coimbatore locations could be due to transfer of virus by its mite vector, the eriophyid mite (Sayiprathap et al., 2020) (Dipshikha et al., 2013).

\section{Acknowledgments}

The authors are thankful to the Director, CPPS, Head of the Department and Professor of Department of Plant Pathology, TNAU, Coimbatore for providing support, guidance and financial assistance. The authors would like to acknowledge DST-FIST for providing facilities at Department of Plant Pathology. Also thankful to the Indian Council of Agricultural Research-Indian Institute of
Horticultural Research (ICAR-IIHR), Bengaluru for permit to done research work.

\section{References}

Dipshikha K, Seweta S, Chandra NB, Chauhan VB, Singh RN (2013)Correlation between mite population (Aceriacajani) and environmental factors causing sterility mosaic disease of pigeonpea. Int J Life Sci 1(3):228-232

Elbeaino T, Digiaro M, Uppala M, Sudini H (2014) Deep sequencing of pigeonpea sterility mosaic virus discloses five RNA segments related to emaraviruses. Virus Res 188:27-31

Elbeaino T, Whitfield A, Sharma M, Digiaro M (2013) Emaravirus-specific degenerate PCR primers allowed the identification of partial RNAdependent RNA polymerase sequences of Maize red stripe virus and Pigeonpea sterility mosaic virus. J Virol Methods 188:37-40

Elbeaino T, Digiaro M, Uppala M, Sudini H (2015) Deep sequencing of dsRNAs recovered from mosaic-diseased pigeonpea reveals the presence of a novel emaravirus: pigeonpea sterility mosaic virus 2. Arch Virol 160:20192029

Kannaiyan J, Nene YL, Reddy MV, Ryan JG, Raju TN (1984) Prevalence of pigeonpea diseases and associated crop losses in Asia,Africa and the Americas. Trop Pest Manag 30(1):62-71

Kulkarni NK, Kumar PL, Muniyappa V, Jones AT, Reddy DVR (2002) Transmission of Pigeonpea sterility mosaic virus by the eriophyid mite, Aceriacajani (Acari: Arthropoda). Plant Dis 86:1297-1303

Kumar PL, Jones AT, Sreenuvasulu P, Reddy DVR (2000) Breakthrough in the identification of the causal agent of 
pigeonpea sterility mosaic disease. $\mathrm{J}$ Mycol Plant Pathol 30:249

Kumar PL, Jones AT, Reddy DVR (2002) Mechanical transmission of Pigeonpea sterility mosaic virus. Journal of Mycology and Plant Pathol 32:88-89

Kumar PL, Jones AT, Reddy DV (2003) A novel mite-transmitted virus with a divided RNA genome closely associated with pigeonpea sterility mosaic disease. Phytopathology 93:718.

Mitra M (1931) Report of the imperial mycologist. Scientific Reports of the Indian Agriculture Research Institute, Calcutta, pp 58-71

Patil BL, Kumar PL (2015) Pigeonpea sterility mosaic virus: a legumeinfecting Emaravirus from South Asia.
Mol Plant Pathol 16:775-786

Patil BP, Meenakshi D, Ritesh M (2017) Variability of emaravirus species associated with sterility mosaic disease of pigeonpea in India provides evidence of segment reassortment. Viruses 9:183

Ramakrishnan K, Kandaswamy TK (1972) Investigations on virus diseases of pulse crops in Tamil Nadu. Final technical report. Tamil Nadu Agricultural University, Coimbatore

Sayiprathap, Patibanda, Prasanna Kumari. (2020) Prevalence of sterility mosaic disease (SMD) and variability in pigeonpea sterility mosaic virus (PPSMV) in southern- India. Indian Phytopathology (2020).

\section{How to cite this article:}

Baskar, S., T. K. S. Latha, G. Karthikeyan, M. Sudha, and Basavaprabhu L. Patil. 2020. Studies on the Molecular Variability of Sterility Mosaic Disease of Pigeonpea in Tamil Nadu State, India. Int.J.Curr.Microbiol.App.Sci. 9(08): 2985-2992. doi: https://doi.org/10.20546/ijcmas.2020.908.336 